\title{
REMOVAL OF DIAZO DYE FROM THE AQUEOUS PHASE BY BIOSORPTION ONTO BALL-MILLED MAIZE COB (BMMC) BIOMASS OF Zea mays
}

\author{
Zvezdelina Yaneva*, Nedyalka Georgieva \\ Chemistry Unit, Department of Pharmacology, Animal Physiology and \\ Physiological Chemistry, Faculty of Veterinary Medicine, \\ Trakia University, Students Campus, 6000 Stara Zagora, Bulgaria \\ z.yaneva@abv.bg
}

\begin{abstract}
The mechanism of Congo red (CR) biosorption by the agricultural waste material ball-milled maize cob (BMMC) biomass of Zea mays was studied by analyzing the effect of $\mathrm{pH}$ and biosorbent surface chemistry; the equilibrium and kinetic behavior of the sorbate/sorbent system were also investigated. Surface chemistry and morphology were characterized by potentiometric titration, $\mathrm{pH}$ of zero charge, FTIR analyses and digital microscopy (DM). The acidic and basic sites for the biomass were quantified as 3.68 and $5.25 \mathrm{mmol} \mathrm{g}^{-1}$, respectively; therefore, the surface of the biomass was basic. The analysis of dye equilibrium isotherm data was done using the Langmuir, Freundlich and Redlich-Peterson models. CR biosorption on the agricultural waste biomaterial was mainly limited by chemisorption and/or intraparticle diffusion. The studies revealed that $\mathrm{CR}$ removal involved electrostatic interactions between negatively charged dye $\mathrm{SO}_{3}{ }^{-}$groups and positively charged adsorbent surfaces, $\mathrm{H}-$ bonding between the oxygenand nitrogen-containing functional groups of $\mathrm{CR}$ and the BMMC surface and hydrophobic-hydrophobic interactions between the dye and sorbent hydrophobic parts. The maximum biosorption capacity of Zea mays biomass $\left(q 4.83 \mathrm{mg} \mathrm{g}^{-1}\right)$ occurred at $\mathrm{pH} 7$.
\end{abstract}

Keywords: Zea mays; Congo red; FTIR; biosorption; equilibrium; kinetics

\section{ОТСТРАНУВАњЕ НА ДИАЗО БОИ ОД ВОДНА ФАЗА СО БИОСОРПЦИЈА НА ПЧЕНКАРНИ КОЧАНИ (Zea mays) СОМЕЛЕНИ СО КУГЛИЧНА ПОСТАПКА}

Беше испитувано влијанието на $\mathrm{pH}$, хемизмот на површината за биосорпција и рамнотежните и кинетичките процеси на системот сорбат/сорбент на механизмот на биосорпцијата на конго црвено (CR), врз биомаса од земјоделски отпаден материјал добиен со мелење на кочани од пченка (Zea mays). Површинските хемиски процеси и морфологијата беа карактеризирани со потенциометриска титрација, pH на нултиот полнеж, како и со FTIR и дигитална микроскопска анализа (DM). Квантитативно беа определени киселите и базните места во биомасата и тие изнесуваат 3,68 and 5,25

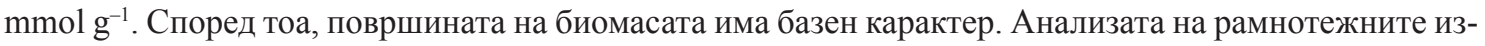
отерми беше направена со Лангмуиров (Langmuir), Фројндлихов (Freundlich) и Редлих-Петерсонов (Redlich-Peterson) модел. Веројатно, биосорпцијата на CR на земјоделскиот отпаден материјал главно е ограничена од хемисорпцијата и/или дифузијата на честичките во внатрешноста. Испитувањата покажуват дека отстранувањето на $\mathrm{CR}$ се одвива со електростатски интеракциии меѓу негативно наелектризираните на $\mathrm{SO}_{3}{ }^{-}$групи и позитивно наелектризираната површина за апсорбција/атсорпција, Н-сврзување меѓу функционалните групи со кислород и азот на CR и на BMMC површината, хидрофобните интеракциии меѓу бојата и хидрофобните делови на сорбентот. Максималниот капацитет за биосорпцијата на биомасата од Zea mays од $q 4,83 \mathrm{mg} \mathrm{g}^{-1}$ беше забележан при $\mathrm{pH} 7$.

Клучни зборови: Zea mays; конго црвено; FTIR; DM; биосорпција; рамнотежа; кинетика 


\section{INTRODUCTION}

Currently, there are more than 100,000 types of dyes, with over 700,000 tons of dyes and pigments produced annually and released into the environment during the dyeing of different substrates, such as synthetic and natural textile fibers, plastics, leather, paper, mineral oils, waxes, and even foodstuffs and cosmetics [1, 2]. Even small quantities of dyes can color large water bodies, which not only affects aesthetic merit but also reduces light penetration and photosynthesis. In addition, most dyes are either toxic or mutagenic and carcinogenic. Thus, their removal from process or waste effluents has become environmentally important [3].

Since September 2003 all European Union legal and customs regulations have prohibited the manufacture and sale of benzidine-based azo dyes [4]. In Turkey, the Turkish government banned the utilization of 130 azo dyes from 1 March 1995 and prohibited the use of these dyes in the textile market. However, they are still used in textile dyeing processes due to their dyeing efficiency and low cost [1].

Congo Red (CR) [1-naphthalenesulfonic acid, 3,3'-(4,4'-biphenylenebis(azo)) bis(4-amino-)disodium salt] is a benzidine-based anionic diazo dye prepared by coupling tetrazotized benzidine with two molecules of napthionic acid [5]. The substance is considered toxic, exhibiting acute algal, bacterial, protozoan, cutaneous, environmental, microbial and yeast toxicity, as well as cytotoxicity, genotoxicity, hematotoxicity, neurotoxicity, carcinogenicity and mutagenicity [6]. The capability of CR to form carcinogenic amines such as benzidine through the cleavage of one or more azo groups is the reason why it falls under the category of banned azo dyes. The recalcitrance of CR has been attributed to the presence of aminobiphenyl group and azo bonds, two features generally considered to be xenobiotic [7]. Thus, the treatment of CR-contaminated wastewater can be complicated due to its complex aromatic structure, providing the dye with physicochemical, thermal and optical stability, and resistance to biodegradation and photodegradation $[8,9]$.

A number of scientific investigations have shown the advantages of adsorption as a very effective separation method which has been considered to be superior to other techniques for water treatment in terms of initial cost, simplicity of design, ease of operation and insensitiveness to toxic substances [10].

In a world of rapid assimilation of natural resources, any attempt regarding the utilization of agricultural wastes and byproducts augments the raw material stock and also provides additional employment and income to marginal farmers and landless agricultural laborers, especially in developing countries [11]. These materials are considered a significant waste disposal problem. They are often used as foodstuffs, energy fuel or compost, etc., but many materials are treated as waste. So, it is promising to utilize these by-products. Agricultural waste materials are economically and environmentally friendly due to their unique chemical composition, availability in abundance, renewable character, low cost and efficiency, and are seen to be viable option for heavy metal and dye remediation [12-14].

A number of lignocellulosic materials, including rice husk, cattail root, neem leaf, sunflower stalk, jute stick powder, orange peel, banana peel, ball-milled sugarcane bagasse, etc., have been studied for CR removal from aqueous systems $[15,16]$. The differences in the performance of these lignocellulosics may be related to their surface chemistry. However, the number of studies subjected to the utilization and application of maize cob agricultural waste as an alternative biosorbent is extremely limited. The literature reports only one study on the adsorption properties of modified maize cob waste for Methyl Orange and As removal from the aqueous phase [17]. The latter fact, combined with the great abundance of this agricultural biomaterial not only in Bulgaria, but worldwide, provoked the current investigation.

The aim of the present study was to assess the physicochemical, spectral, equilibrium 
and kinetic aspects of Congo red biosorption on pristine ball-milled maize cob biomass, demonstrating the effect of a number of factors on the mechanism of the process and the probable sorbate/sorbent interactions.

\section{EXPERIMENTAL}

\subsection{Sorbate}

Congo red (C.I. 22120) was supplied by Sigma-Aldrich. The stock solution of CR was prepared by dissolving the required amount of the dye in distilled water. The experimental single component model solutions were obtained by diluting the stock solution of $\mathrm{CR}$ with distilled water to the desired initial concentration. Calibration curves at different solution $\mathrm{pH}$ values were prepared by measuring the absorbance at different dye concentrations. The structural chemical formula, physicochemical and molecular characteristics of the synthetic azo dye are presented in Table 1. All other chemicals used to remove any adhering substances were procured from Merck, Germany.

Table 1

Physicochemical characteristics of $C R[6,18]$

\begin{tabular}{|c|c|}
\hline CAS No. & $573-58-0$ \\
\hline CA Index name & $\begin{array}{l}\text { 1-Naphthalenesulfonic acid, 3,3'-[(1,1'-biphenyl)-4,4 '-diylbis(2,1-diazenediyl) }] \text { bis[4- } \\
\text { amino-sodium salt (1:2)] }\end{array}$ \\
\hline C.I. number & 22120 \\
\hline Chemical structure & $\mathrm{SO}_{3} \mathrm{Na}$ \\
\hline Molecular formula & $\mathrm{C}_{32} \mathrm{H}_{22} \mathrm{~N}_{6} \mathrm{Na}_{2} \mathrm{O}_{6} \mathrm{~S}_{2}$ \\
\hline Molecular weight & $696.66 \mathrm{~g} \mathrm{~mol}^{-1}$ \\
\hline Molecular surface area & $557.6 \AA^{2}$ \\
\hline Physical form & brownish-red powder \\
\hline Solubility & $\begin{array}{l}\text { soluble in water, ethanol; very slightly soluble in acetone; practically insoluble in } \\
\text { ether, xylene }\end{array}$ \\
\hline Density & $0.995 \mathrm{~g} \mathrm{~cm}^{-3}$ at $25^{\circ} \mathrm{C}$ \\
\hline Dye class & azo \\
\hline Melting point & $>360^{\circ} \mathrm{C}$ \\
\hline Color & blue ( $\mathrm{pH} 3.0)$ to red ( $\mathrm{pH} 5.0)$ \\
\hline $\mathrm{pKa}$ & 3.0 \\
\hline Absorption wavelength $\left(\lambda_{\max }\right)$ & $498 \mathrm{~nm}$ \\
\hline
\end{tabular}

\subsection{Preparation of ball-milled maize $c o b$ (BMMC) Zea mays biosorbent}

The maize cobs of Zea mays used in the present investigations were obtained from a local countryside farm (Kolarovo Village,
Stara Zagora District, Bulgaria) in 2011. The collected materials were thoroughly washed with distilled water several times to remove dust and any adhering substances. The washed material was oven dried at $373 \mathrm{~K}$ for $24 \mathrm{~h}$. Then, the dried biomass was milled and sieved 
to retain the $0.2-1.0 \mathrm{~mm}$ fraction. The prepared sample was stored in an airtight container for further analyses and biosorption studies. No other chemical or physical treatments were applied prior to the sorption experiments.

\subsection{Surface chemistry characterization of the biosorbent}

The surface chemistry of the biosorbent was characterized by Boehm titration, $\mathrm{pH}$ of zero charge, FTIR and digital microscopy (DM).

\subsubsection{Potentiometric titration and point of zero charge $\left(\mathrm{pH}_{\mathrm{PZC}}\right)$}

Acidic and basic sites on BMMC waste biomass were determined by the acid-base titration (potentiometric titration) method proposed by Boehm [19]. The total acidic sites were neutralized using $\mathrm{NaOH}\left(0.1 \mathrm{~mol} \mathrm{dm}^{-3}\right)$, while the basic sites were neutralized with $\mathrm{HCl}$ $\left(0.1 \mathrm{~mol} \mathrm{dm}^{-3}\right)$. The titrations were performed in Erlenmeyer flasks over a magnetic stirrer. Protonation was carried out by soaking the biomass $(1 \mathrm{~g})$ in $0.1 \mathrm{M} \mathrm{HCl}\left(50 \mathrm{~cm}^{3}\right)$ and agitating for $2 \mathrm{~h}$ on a rotary shaker at room temperature. The titration procedure was executed slowly, by the stepwise addition of the titrant $(0.1 \mathrm{M} \mathrm{NaOH})$ to the biosorbent slurry. After each addition of titrant $\left(0.25 \mathrm{~cm}^{3}\right)$, the system was allowed to equilibrate until a stable reading was obtained. The total volume of $\mathrm{NaOH}$ utilized for neutralization was recorded for total basic site calculations. Likewise, the total acidic sites were determined by keeping the biomass $(1 \mathrm{~g})$ in $0.1 \mathrm{M} \mathrm{NaOH}$ solution $\left(50 \mathrm{~cm}^{3}\right)$ and performing titration similar to as described above. The potentiometric titration curves were obtained by plotting the volume of titrant against the recorded $\mathrm{pH}$.

The $\mathrm{pH}_{\mathrm{PZC}}$ corresponds to zero surface charge density, i.e. to equivalent amounts of negative and positive charges developed by proton equilibria. If no specific adsorption of ions occurs, the point of zero charge coincides with the isoelectric point, whereas specific adsorption of ions causes a discrepancy between the isoelectric and zero charge points. The determination of these values provides information on the specificity of adsorption [20].

The zero surface charge characteristics of BMMC were determined using the solid addition method [21]. $40 \mathrm{~cm}^{3}$ of $0.1 \mathrm{M} \mathrm{NaCl}$ solution were transferred to a series of 250 $\mathrm{cm}^{3}$ stoppered conical flasks. The $\mathrm{pH}_{\mathrm{i}}$ values of the solutions were adjusted between 2 and 11 by adding either $0.1 \mathrm{M} \mathrm{HCl}$ or $\mathrm{NaOH}$ and were measured using a Consort $\mathrm{C} 931 \mathrm{pH}$ meter (Belgium). The total volume of the solution in each flask was adjusted to exactly $50 \mathrm{~cm}^{3}$ by adding $\mathrm{NaCl}$ solution of the same strength. The $\mathrm{pH}_{\mathrm{i}}$ of the solution was then accurately noted. $0.5 \mathrm{~g}$ of BMMC was added to each flask, and the flask was securely capped immediately. The suspensions were then kept shaking for $24 \mathrm{~h}$ and allowed to equilibrate for $0.5 \mathrm{~h}$. The final $\mathrm{pH}$ values of the supernatant liquids were noted. The difference between the initial and final $\mathrm{pH}$ $\left(\mathrm{pH}_{\mathrm{f}}\right)$ values $(\Delta \mathrm{pH})$ was plotted against the $\mathrm{pH}_{\mathrm{i}}$. The point of intersection of the resulting curve with the , i.e. at $\mathrm{pH} 0$, gave the $\mathrm{pH}_{\mathrm{PzC}}$.

\subsubsection{FTIR and morphological analyses}

The functional groups present in the fresh and dye-loaded BMMC were characterized by a Fourier transform infrared spectrometer (TENSOR 37 Bruker), using potassium bromide discs to prepare the samples. The spectral range varied from 4000 to $400 \mathrm{~cm}^{-1}$. The microscopic morphological analyses BMMC before and after CR biosorption were conducted using a digital microscope at a magnification of $500 \times$.

\subsection{Effect of $p H$}

The effect of $\mathrm{pH}$ was investigated by a series of biosorption experiments at an initial dye concentration $\left(C_{\mathrm{o}}\right)$ of $30 \mathrm{mg} \mathrm{dm}^{-3}$, 
a biosorbent mass $(w)$ of $0.5 \mathrm{~g}$, a volume of the model solution of $100 \mathrm{~cm}^{3}$ and at $\mathrm{pH} \mathrm{2,4}$, 7, 9 and 11. The $\mathrm{pH}$ of the dye solutions was adjusted by the addition of $0.1 \mathrm{M} \mathrm{NaOH}$ or 0.1 $\mathrm{M} \mathrm{HCl} . \mathrm{pH}$ values were measured on a Consort C931 pH meter (Belgium).

\subsection{Equilibrium studies}

Equilibrium biosorption experiments were carried out by agitating a predetermined mass of BMMC with $100 \mathrm{~cm}^{3}$ of CR solutions with initial concentrations in the range of $5-50 \mathrm{mg} \mathrm{dm}^{-3}$ at a temperature $T$ of $19 \pm 2{ }^{\circ} \mathrm{C}$ and $\mathrm{pH}$ 7.0. The sorbate/ sorbent systems were agitated until equilibrium. Then, the dye solutions were separated from the adsorbent by centrifugation with a Heraeus Labofuge200 (Thermo, Electron Corporation) at $5,300 \mathrm{~g}$ for $20 \mathrm{~min}$ and filtered using 0.45 $\mu \mathrm{m}$ membrane filters (LCW 916, Hach Lange, Germany) to ensure the solutions were free from adsorbent particles before measuring the residual dye concentration. The residual CR concentrations were determined spectrophotometrically by monitoring the absorbance at $498 \mathrm{~nm}$ using a UV/ VIS DR 5000 spectrophotometer (Hach Lange, Germany). All experiments were carried out in triplicate, and the average values were taken to minimize random error. Blanks containing no adsorbate and replicates of each adsorption point were used for each series of experiments. The corresponding values of $\mathrm{CR}$ solid phase concentrations $\left(q_{e}\right)$ were calculated by the mass balance equation (1):

$$
\left(C_{o}-C_{e}\right) \cdot V=\left(q_{e}-q_{o}\right) \cdot w
$$

where $C_{\mathrm{o}}$, in $\mathrm{mg} \mathrm{dm}^{-3}$, is the initial dye concentration in the liquid phase, $q_{\mathrm{o}}=0$, and $w$, in $\mathrm{g}$, is the biosorbent mass.

\subsection{Kinetic studies}

The kinetic experiments were conducted in a standardized batch adsorber with a twobladed impeller [22]. The kinetic experiments were carried out at initial CR concentration $C_{\mathrm{o}}$ $5 \mathrm{mg} \mathrm{dm}^{-3}$, and masses of the adsorbent $w 0.5,1$ and $3 \mathrm{~g}$ at an agitation rate $n$ of $200 \mathrm{rpm}, T 19 \pm 2$ ${ }^{\circ} \mathrm{C}$ and $\mathrm{pH}$ 7.0. The residual CR concentrations were determined spectrophotometrically by monitoring the absorbance at $498 \mathrm{~nm}$ using a UV/VIS DR 5000 Spectrophotometer (Hach Lange, Germany). All experiments were carried out in triplicate, and the average values were taken to minimize random error. Blanks containing no adsorbate and replicates of each adsorption point were used for each series of experiments.

The dye removal percentage $(E, \%)$ was calculated as follows:

$$
E=\frac{C_{o}-C_{e}}{C_{o}} \cdot 100 \%
$$

\subsection{Mathematical modelling}

The biosorption behavior of CR on Zea mays biomass in the present research was modeled by the Langmuir, Freundlich and Redlich-Peterson isotherm equations (Table 2).

The kinetic experimental results were modeled by the pseudo-first and pseudo-second order kinetic models and the intraparticle diffusion model (Table 3).

The kinetic experimental results were modeled by the pseudo-first and pseudo-second order kinetic models and the intraparticle diffusion model (Table 3).

\subsection{Error analysis}

Due to the inherent bias resulting from linearization of the isotherm models, the nonlinear-regression Chi-square $\left(\chi^{2}\right)$ test was employed as a criterion for the quality of fitting. This statistical analysis is based on the sum of the squares of the differences between the experimental data and data obtained by calculating from models, with each squared difference divided by the corresponding data obtained by 
a b 1 e 2

Mathematical equations of the applied single component isotherm models

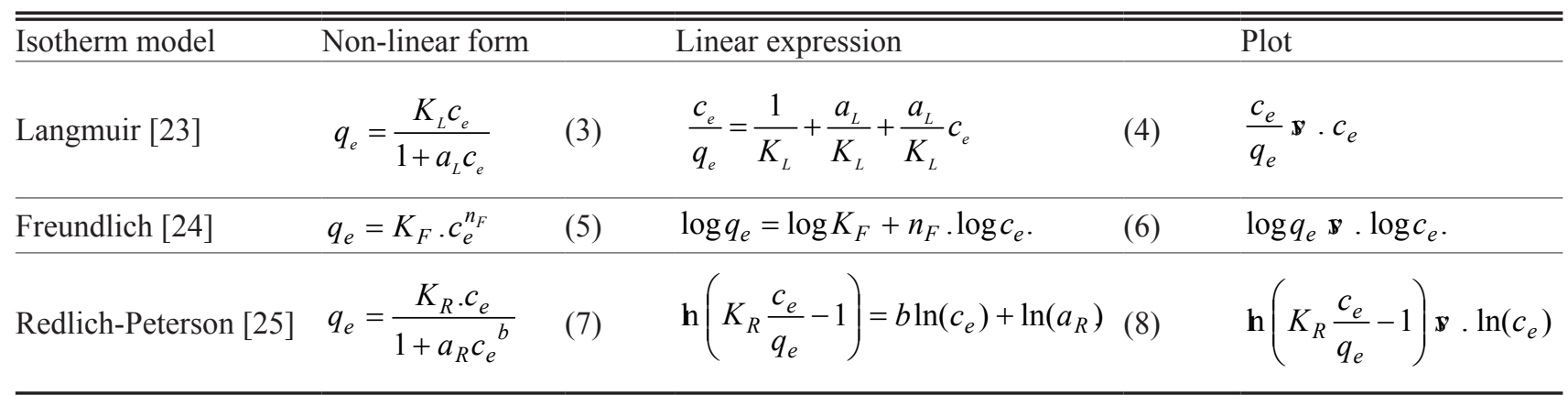

Ta b le 3

Kinetic and mass transfer models

\begin{tabular}{llll}
\hline \hline Model & Non-linear form & Linear expression \\
\hline Pseudo-first order kinetic model [26] & $\frac{d q_{t}}{d t}=k_{1}\left(q_{e}-q_{t}\right)$ & (9) & $\log \left(q_{e}-q_{t}\right)=\log q_{e}-\frac{k_{1}}{2.303} t$ \\
\hline & $\frac{d q_{t}}{d t}=k_{2}\left(q_{e}-q_{t}\right)^{2}$ & (11) & $\frac{t}{q_{t}}=\frac{1}{k_{2} q_{e}{ }^{2}}+\frac{1}{q_{e}} t$ \\
Pseudo-second order kinetic model [27] & $\frac{1}{q_{e}-q_{t}}=\frac{1}{q_{e}}+k_{2} t$ & $(12)$ & \\
\hline Intraparticle diffusion model [28, 29] & $q_{t}=k_{i} t^{0.5}+I$ & $(14)$ & \\
\hline \hline
\end{tabular}

calculating from models. The Chi-square can be represented by Equation (15):

$$
\chi^{2}=\sum\left[\frac{\left(q_{e}^{\text {exp }}-q_{e}^{\text {cal }}\right)^{2}}{q_{e}^{\text {cal }}}\right]
$$

where $q_{e}^{\text {exp }}$ is the equilibrium adsorption capacity from the experiment $\left(\mathrm{mg} \mathrm{g}^{-1}\right)$, and $q_{e}^{\text {cal }}$ is the equilibrium capacity calculated according to the model $\left(\mathrm{mg} \mathrm{g}^{-1}\right)$. A small value of $\chi^{2}$ indicates that data from the model is similar to the experimental value, whereas a large value of $\chi^{2}$ points out a difference between them. In order to confirm the best-fit isotherms and kinetic models for the biosorption system, there was a need to analyze the data set using the Chisquare test, combined with the value of the correlation coefficient $\left(R^{2}\right)$ [30].

\section{RESULTS AND DISCUSSION}

To understand the biosorption mechanism, it is necessary to determine the concentrations of the surface active groups, the point of zero charge $\left(\mathrm{pH}_{\mathrm{PZC}}\right)$ of the biosorbent and to analyze changes in the sorbent spectra before and after sorption, as well as in the surface morphology of the fresh and dye-loaded sorbent.

\subsection{Structural, spectral and morphological characterization of $B M M C$}

\subsubsection{Potentiometric titration}

Testing for the determination of acidic and basic sites and functional groups present on cell wall of the biomass was performed by potentio- 


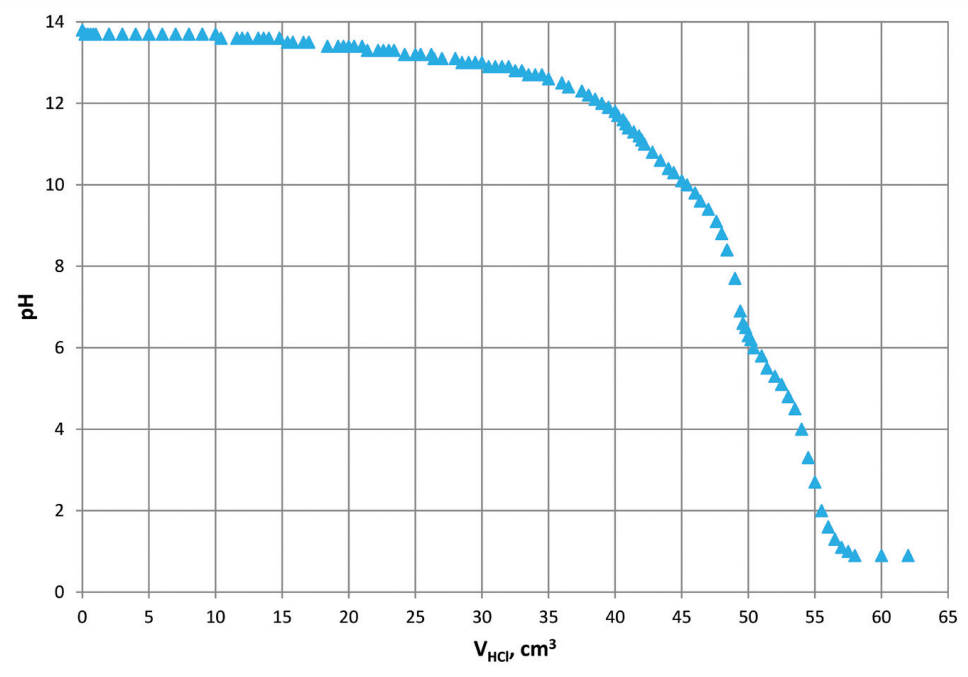

a)

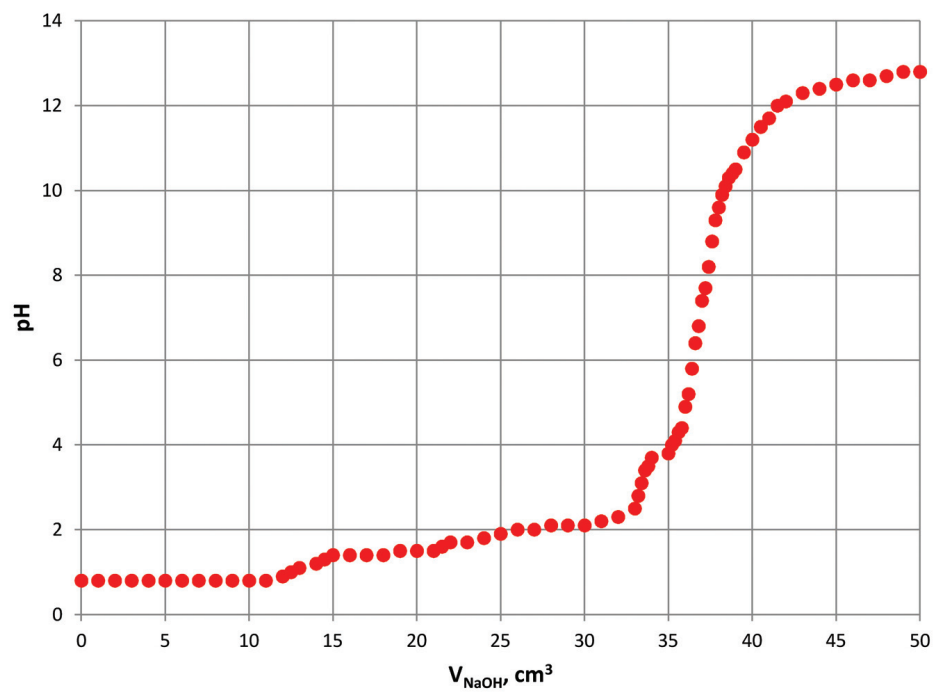

b)

Fig. 1. Potentiometric titration curve of BMMC suspension for: a) acidic sites and b) basic sites ( $w 1 \mathrm{~g} ; V 50 \mathrm{~cm}^{3} 0.1 \mathrm{M} \mathrm{HCl} / 0.1 \mathrm{M} \mathrm{NaOH} ; n 700 \mathrm{rpm}, T 20^{\circ} \mathrm{C}, t 2 \mathrm{~h}$ )

metric titration. In order to gain closer insight into the surface properties of the agricultural waste product for acidic sites, a biomass suspension in $0.1 \mathrm{M} \mathrm{HCl}$ was potentiometrically titrated with 0.1 $\mathrm{M} \mathrm{NaOH}$ (Figure 1A). Likewise, an $\mathrm{NaOH}$ suspension of biomass was potentiometrically titrated with $0.1 \mathrm{M} \mathrm{HCl}$ for the determination of basic sites. The respective curve is presented in Figure $1 \mathrm{~B}$.
Both titration curves displayed, respectively, four and five inflection points, and the corresponding $\mathrm{pKa}$ values suggest the binding of functional groups present on the cell wall of the biomass. The titration results permitted the qualitative and semi-quantitative determination of the nature and number of active (acidic or basic) sites present on the biomass. The curve in Figure 1A shows four inflection points at 
approximately $\mathrm{pH} 3.5,4.3,6.0$ and 6.7, corresponding to $\mathrm{pKa}$ values of acidic binding groups and four inflection points at approximately $\mathrm{pH}$ $8.5,10.0,11.1$ and 12.5, corresponding to alkaline functional groups. It may be inferred that acidic groups were carboxylic (pKa 1.7-4.7), imidazole (pKa 5.5-6.0) and phosphate (pKa 6.1-6.8) and the alkaline groups were comparable to the values reported for amines ( $\mathrm{pKa}$ 8.0-11.0), sulfhydryl (thiol) (pKa 8.0-10.0) and hydroxyl (pKa 9.5-13).
The curve in Figure 1B shows inflection points around $\mathrm{pH} 12.0$ and $\mathrm{pH} 10.5$ for hydroxyl $(-\mathrm{OH})$ and amine $(-\mathrm{NH})$ as the alkaline binding groups. The acidic functional groups noted were mainly carboxylic (pKa $2.2 ; 4.0$ ). According to the experimental data, the acidic and basic sites for BMMC were estimated to be 3.68 and 5.25 mmol $\mathrm{g}^{-1}$, respectively. It was observed that the concentration of basic sites was higher than that of acidic sites; hence, the surface of the biomass was basic.

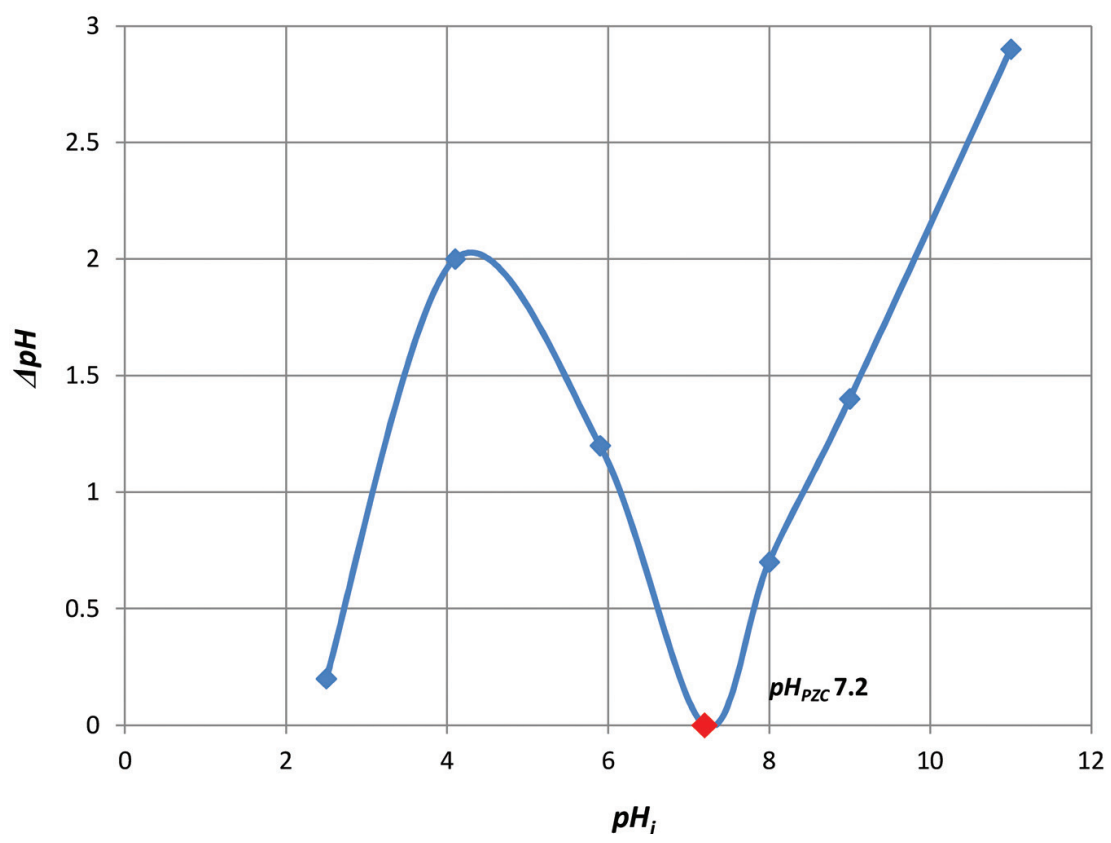

Fig. 2. Determination of $\mathrm{pH}_{\mathrm{PZC}}$ of $\mathrm{BMMC}$

\subsubsection{Point of zero charge}

It can be observed from Figure 2 that the surface charge of BMMC at $\mathrm{pH} 7.2$ is zero.

Hence, the $\mathrm{pH}_{\mathrm{PZC}}$ at point of zero charge of the biosorbent is 7.2. According to the literature, the adsorption of cations is favored at $\mathrm{pH}>$ $\mathrm{pH}_{\text {PZC }}$, while the adsorption of anions is favored at $\mathrm{pH}<\mathrm{pH}_{\mathrm{PZC}}$ [5]. Thus, the determination of this parameter is significant for the assessment of the biosorption mechanism and the probable sorbate/sorbent interactions.

\subsubsection{Analyses of BMMC biomass morphology}

The DM images of the BMMC biosorbent before and after CR sorption, presented in Figure $3 \mathrm{~A}$ and $\mathrm{B}$, respectively, display the heterogeneity of Zea mays biomass and the irregular distribution of dye macromolecules on irregular regions of the solid particle surface. 


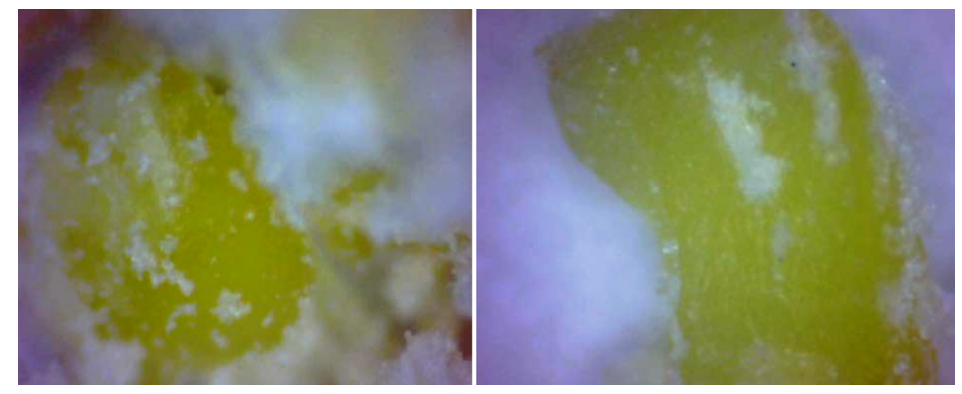

(A)

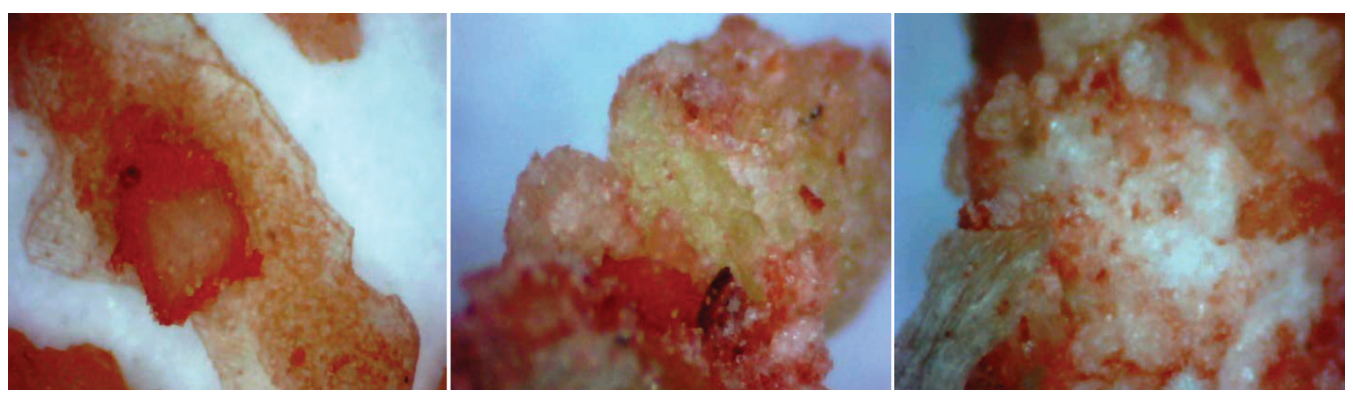

(B)

Fig. 3. Digital microscope images (500×) of: (A) fresh BMMC and (B) CR-loaded BMMC

Consequently, based on the morphology, it can be concluded that the agricultural waste material investigated presents an adequate morphological profile to retain dye ions.

\subsubsection{FTIR analyses of BMMC}

The adsorption of CR on BMMC was also affected by other interactions between functional groups of $\mathrm{CR}$ and $\mathrm{BMMC}$ in addition to electrostatic interactions. FTIR analyses were conducted in order to identify the possible locations of these interactions. The FTIR spectra of fresh and dye-loaded BMMC, measured within the range of $4000-400 \mathrm{~cm}^{-1}$, are shown in Figure $4 \mathrm{~A}, \mathrm{~B}$. The interpretation of the FTIR spectral data, including the assignment of the observed peaks and spectral differences between the fresh and CR-loaded BMMC, is displayed in Table 4.

The slight change in the shape of the broad band in the region between $3100 \mathrm{~cm}^{-1}$ and $3400 \mathrm{~cm}^{-1}$ after adsorption may also be associated with interactions between Zea mays hydroxyl groups and $\mathrm{CR}$. The changes observed between 1660 and $1500 \mathrm{~cm}^{-1}$ might be due to the electrostatic forces of attraction between the negative charge of carboxylate anions and positive groups of the dye [31].

The major differences were the absorption band at $3308 \mathrm{~cm}^{-1}$, corresponding to the stretching vibration of $\mathrm{O}-\mathrm{H}$ and $\mathrm{N}-\mathrm{H}$ on BMMC, which was diminished after $\mathrm{CR}$ biosorption and shifted to a lower wavenumber $\left(3252 \mathrm{~cm}^{-1}\right)$. This is indicative of hydrogen bond formation between the hydroxyl groups of BMMC and the amine group of dye molecules. The new absorption peak at $713 \mathrm{~cm}^{-1}$ observed after CR adsorption could be assigned to the characteristic adsorption of aromatic skeletal groups [32]. The region between 700 and 900 $\mathrm{cm}^{-1}$ contains various bands related to aromatic, out of plane $\mathrm{C}-\mathrm{H}$ bending with different degrees of substitution [33]. 


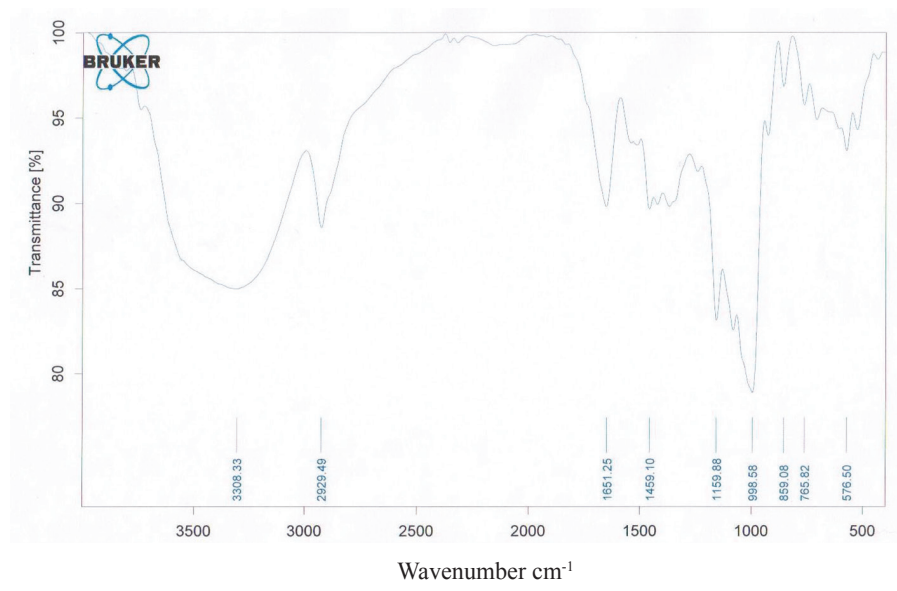

(A)

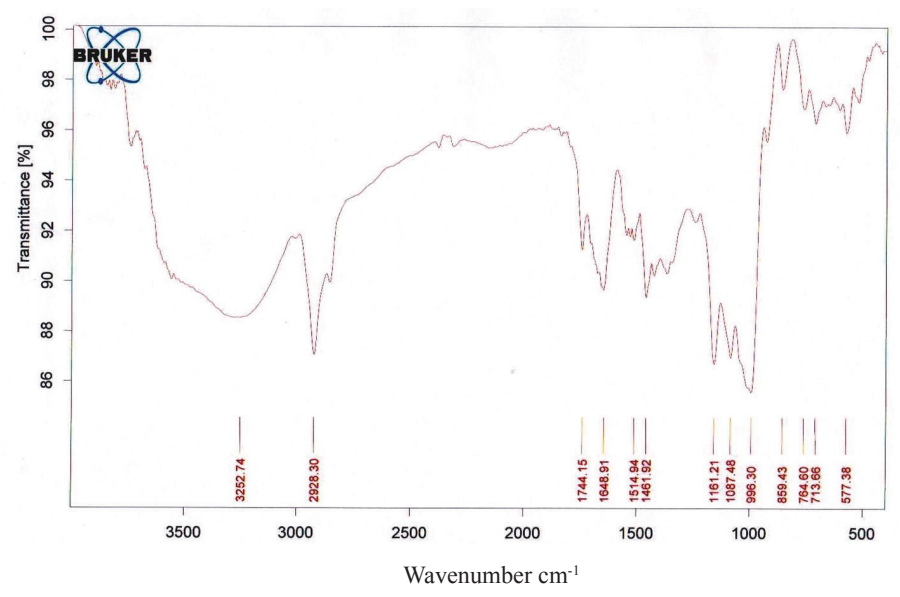

(B)

Fig. 4. FTIR spectra of: (A) pristine BMMC and (B) dye-loaded BMMC

Table 4

FTIR spectral data of fresh and CR-loaded BMMC (Zea mays)

\begin{tabular}{cccl}
\hline \hline \multicolumn{2}{c}{ Frequency, $\mathrm{cm}^{-1}$} & \multirow{2}{*}{ Difference } & Assignment \\
\cline { 1 - 2 } Before biosorption & After biosorption & & \\
\hline 3308.33 & 3252.74 & 55.59 & $-\mathrm{OH}$ stretching; $-\mathrm{NH}$ stretching \\
2929.49 & 2928.30 & 1.19 & $-\mathrm{CH}$ stretching aliphatic (strong) \\
& 1744.15 & & $-\mathrm{C}=\mathrm{O}$ stretching aldehyde \\
1651.25 & 1648.91 & 2.34 & $-\mathrm{C}=\mathrm{O}$ stretching amide (strong) \\
& 1514.94 & & $-\mathrm{N}-\mathrm{O}$ stretching nitro; \\
1459.10 & 1461.92 & -2.82 & $-\mathrm{C}-\mathrm{H}$ bending alkane; $v \mathrm{C}-\mathrm{O}$ carboxylic groups \\
1159.88 & 1161.21 & -1.33 & $-\mathrm{P}=\mathrm{O}$ stretching vibration \\
& 1087.48 & & $-\mathrm{C}-\mathrm{N}$ stretching; \\
$900-700$ & $900-700$ & & $-\mathrm{CH}$ out of plane aromatic bending vibrations \\
\hline \hline
\end{tabular}




\subsection{Biosorption studies}

\subsubsection{Effect of $p H$}

Adsorbate solution $\mathrm{pH}$ affects the adsorption capacity of an adsorbent through modification of the state of ionization of binding groups, either by increasing or decreasing the competition between protonated species and adsorbate molecules for active sites. Therefore, the optimal $\mathrm{pH}$ depends on the chemical nature of the adsorbate and adsorbent. Hence, the present investigations studied both aspects of the $\mathrm{pH}$ effect on the UV/VIS spectral characteristics of the dye, and on the extent of CR biosorption on agricultural waste biomass.

\subsubsection{Effect of $p H$ on the spectral characteristics of $C R$}

Congo red contains an azo $(-\mathrm{N}=\mathrm{N}-)$ chromophore and an acidic auxochrome $\left(-\mathrm{SO}_{3} \mathrm{H}\right)$ associated with the benzene structure. $\mathrm{CR}$ in aqueous solution exhibited a main band at $\lambda 488-500 \mathrm{~nm}$, assigned to the absorption band of the anionic monomer, and associated with two absorption bands in the UV-region at $\lambda 265$ and $344 \mathrm{~nm}$, attributed to the benzoic and naphthalene rings, respectively (Figure 5). The UV/VIS spectra of $\mathrm{CR}$ at $\mathrm{pH} 2,4,7,9$ and 11 showed that the dye monomers had nearly constant absorption bands and absorbance intensities over the $\mathrm{pH}$ range of 7-11, which means that aggregation,

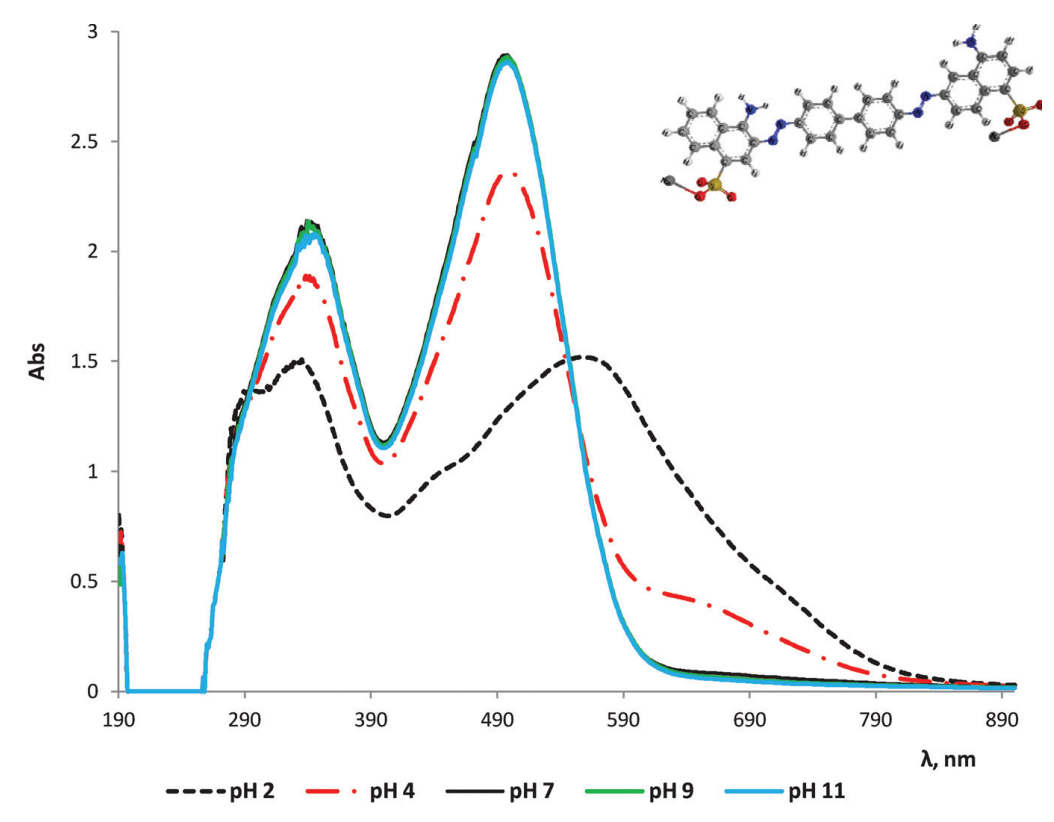

Fig. 5. Effect of $\mathrm{pH}$ on the UV/VIS spectra of CR

did not occur. However, in acidic medium, the main band of the CR monomer gradually shifted to longer wavelengths, almost reaching $555 \mathrm{~nm}$ at $\mathrm{pH} 2[34,35]$. The intensity decreases and red shift of CR monomer bands are attributed to partial self-association of CR monomers as anionic dimers in a face-to-face arrangement to minimize their hydrophobic interactions with water. For that reason, the present biosorption investigations were conducted only within the neutral $\mathrm{pH}$ range.

\subsubsection{Effect of $p H$ on the biosorption process}

Theoretically, at $\mathrm{pH}<$ isoelectric point (pKa), the surface is positively charged, which enhances the adsorption of negatively charged dye anions through electrostatic forces of attraction. At $\mathrm{pH}>\mathrm{pKa}$, the surface of the biosorbent particles becomes negatively charged, which makes $\mathrm{OH}^{-}$ions compete effectively with dye 
anions, causing a decrease in dye adsorption [36]. As the $\mathrm{pKa}$ of $\mathrm{CR}$ is 3 , in the $\mathrm{pH}$ range of 4-11, dye ions will be negatively charged. The experimental results of the effect of $\mathrm{pH}$ on the biosorption behavior of $\mathrm{CR}$ are graphically presented in Figure 6. Obviously, the maximum biosorption capacity of BMMC ( $q 4.83 \mathrm{mg} \mathrm{g}^{-1}$ ) was registered at $\mathrm{pH}$ 7. At $\mathrm{pH}<\mathrm{pH}_{\mathrm{PZC}}$, the solid surface of the biomaterial was positively charged, which is a favorable condition for electrostatic interactions between dye anions and the positively charged adsorbent surface. Besides, in neutral medium $\mathrm{OH}^{-}$and $\mathrm{H}^{+}$concentrations are equal, thus they would not compete for binding to the active biosorbent sites. The biosorption of the anionic dye decreased with an increase in $\mathrm{pH}$ ( $\mathrm{pH}$ 8-9), and this phenomenon was associated not only with the negative charge on the surface of the adsorbent but also with excess $\mathrm{OH}^{-}$ions in the solution that compete for the adsorption sites on BMMC.

Based on the results obtained and the analyses made, the major mechanisms responsible for CR biosorption on BMMC include: electrostatic interactions between negatively charged dye $\mathrm{SO}_{3}^{-}$groups and positively charged adsorbent surfaces, $\mathrm{H}$-bonding between oxygen- and nitrogen-containing functional groups of $\mathrm{CR}$ and the BMMC surface and hydrophobic-hydrophobic interactions between the hydrophobic parts of the dye and the sorbent.

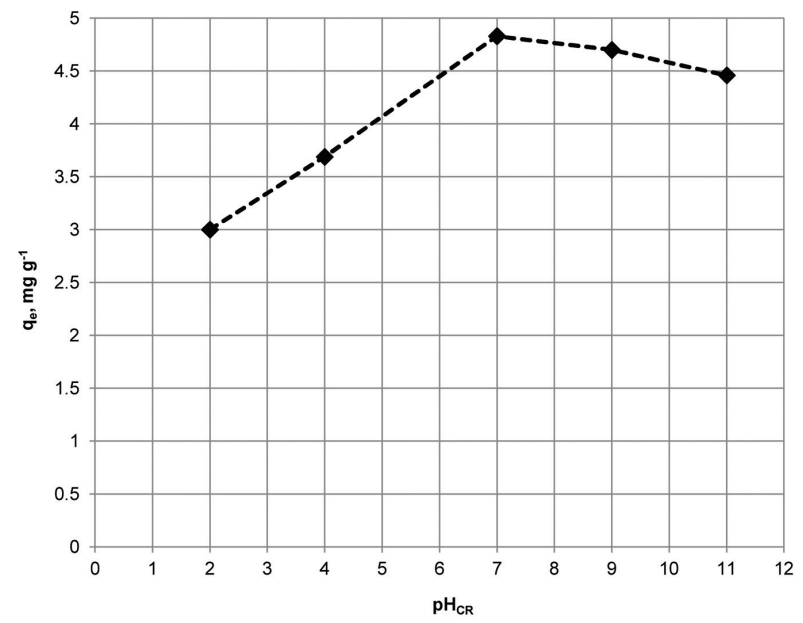

Fig. 6. Effect of $\mathrm{pH}$ on $\mathrm{CR}$ biosorption by BMMC

\subsubsection{Biosorption equilibrium}

The experimental data of CR biosorption on BMMC was modeled according to the Langmuir, Freundlich and Redlich-Peterson equations. The values of the calculated parameters, correlation coefficients and $\chi^{2}$ are presented in Table 5.

It was established that the maximum equilibrium capacity of BMMC towards CR was $q_{\max }$ $4.0 \mathrm{mg} \mathrm{g}^{-1}$, while the monolayer capacity according to the Langmuir model defined as $K_{\mathrm{L}} / a_{\mathrm{L}}$ was $9.31 \mathrm{mg} \mathrm{g}^{-1}$.

Table 5

Values of Langmuir, Freundlich and RedlichPeterson isotherm constants and error criteria

\begin{tabular}{lccc}
\hline \hline \multicolumn{1}{c}{ Model } & Langmuir & Freundlich & $\begin{array}{c}\text { Redlich- } \\
\text { Peterson }\end{array}$ \\
\hline $\begin{array}{l}\text { Model } \\
\text { parameters }\end{array}$ & $K_{\mathrm{L}} 0.2449$ & $K_{\mathrm{L}} 0.02857$ & $\begin{array}{c}K_{\mathrm{R}} 0.2449 \\
n_{\mathrm{F}} 0.8139\end{array}$ \\
$\begin{array}{c}a_{\mathrm{R}} 0.0252 \\
b 0.9482\end{array}$ \\
$\begin{array}{l}\text { Correlation } \\
\text { coefficient }\end{array}$ & $R^{2} 0.7305$ & $R^{2} 0.9678$ & $R^{2} 0.6143$ \\
Chi-square & $\chi^{2} 0.1262$ & $\chi^{2} 0.2131$ & $\chi^{2} 0.1530$ \\
\hline \hline
\end{tabular}

Figure 7 presents the experimental data and the Langmuir, Freundlich and RedlichPeterson model isotherms. The Freundlich isotherm was characterized with the highest $R^{2}$ value $\left(R^{2} 0.9678\right)$ and $1 / n>1$, indicating the favorable nature of biosorption. Additionally, the Freundlich isotherm model is valid for multilayer adsorption and is derived by assuming a heterogeneous surface with interaction between adsorbed molecules with a non-uniform distribution of the heat of sorption. However, the $\chi^{2}$ for the Freundlich model displayed the highest value, while that for the Langmuir equation was the lowest (Table 5).

The Redlich-Peterson model, however, provided a satisfactory approximation of the experimental points, especially in the low and middle concentration range. Unlike the Freundlich isotherm, the Langmuir isotherm is valid for the adsorption of a solute from a liquid solu- 
tion as monolayer adsorption on a surface containing a finite number of identical sites. Figure 7 demonstrates the better applicability of the Langmuir model in the low and high concentration ranges. Considering that it was character- ized by the lowest $R^{2}$ and $\chi^{2}$ values, however, a general conclusion regarding the best fitting model could not be drawn. Obviously, both twoparameter models could successfully describe the equilibrium behavior of the studied system.

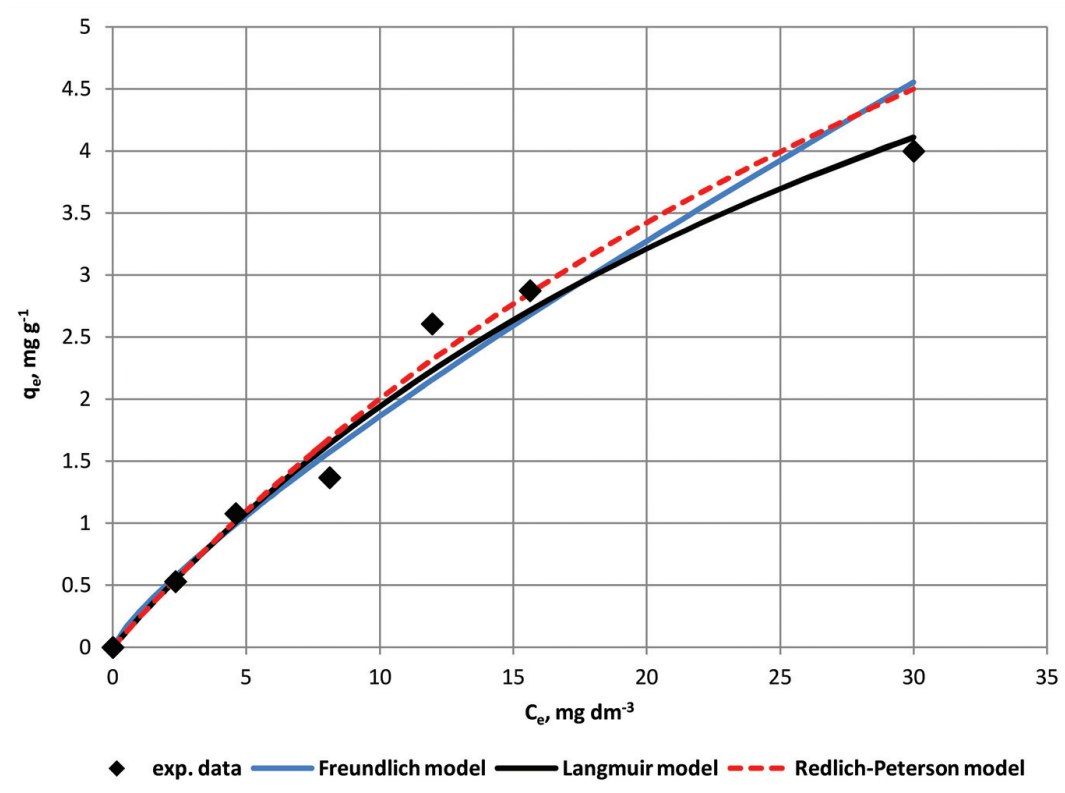

Fig. 7. Experimental and model equilibrium isotherms for the system $\mathrm{CR} / \mathrm{BMMC}$

\subsubsection{Biosorption kinetics}

The experimental kinetic curves (Figure 8) displayed an outlined direct relationship between biomaterial quantity and the extent of dye uptake from the model solutions. The latter statement was logical as a greater amount of biosorbent is related to a larger number of vacant active sites for organic molecule sorption. The sorption rate in the initial stages of the process was the highest. The system reached equilibrium, indicated by the horizontal section of the kinetic curves, approximately 40-50 min after the initiation of the process. The highest adsorption capacity attained was $q_{e} 4.73 \mathrm{mg} \mathrm{g}^{-1}$. The experimental data were modeled by the pseudo-first order and pseudo-second order kinetic models and the intraparticle diffusion model to determine the prevailing mechanism(s) occurring during $\mathrm{CR}$ biosorption on the biomaterial and to examine the effect of adsorbent mass on the kinetic and diffusion parameters of the models. Table 6 lists the values of the rate constants $\left(k_{1}, k_{2}, k_{\mathrm{i}}\right)$ the initial sorption rate $(h)$, sorption capacity $\left(q_{e 1}, q_{e 2}\right)$ and the regression coefficients $\left(R_{1}^{2}, R_{2}^{2}, R_{i}^{2}\right)$ calculated according to the kinetic and mass transfer models applied to the experimental data.

The high values of the correlation coefficients $\left(R_{2}^{2}>0.9990\right)$ and the approximately equal values of the calculated and experimentally obtained equilibrium adsorption capacities $\left(q_{e 2}, q_{\text {exp }}\right)$ (Table 6$)$, calculated by the pseudo-second order model compared to the values of the parameters obtained by applying the first order equation (Table 6), showed the better applicability of the second order model. The latter conclusion was also sustained by the comparative analyses of the modes of the experimental and pseudo-second-order model kinetic curves, plotted as $q_{t}=f(t)$ (Figure 8). Thus, chemisorption could be accepted as one of the basic rate limiting mechanisms during CR sorption on Zea mays biomass. 


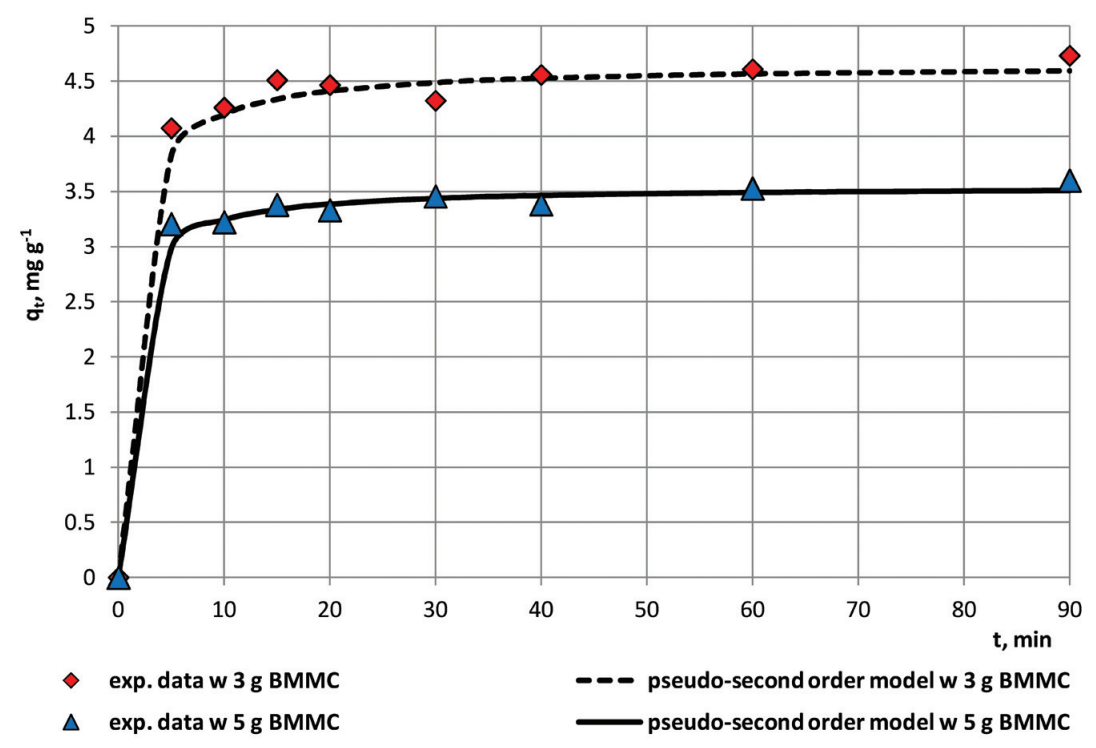

Fig. 8. Experimental and pseudo-second-order kinetic curves for the CR-BMMC system $\left(C_{\mathrm{o}} 30 \mathrm{mg} \mathrm{dm}{ }^{-3} ; w 3 \mathrm{~g} ; V 900 \mathrm{~cm}^{3} ; n 200 \mathrm{rpm} ; \mathrm{pH} 7.0\right)$

T a b l e 6

Values of the kinetic and diffusion parameters characterizing CR biosorption by BCCM - the effect of biosorbent mass. Conditions: $C_{o} 30 \mathrm{mg} \mathrm{dm^{-3 }}$, pH 7.0, T $19 \pm 2{ }^{\circ} \mathrm{C} ; \mathrm{n} 200 \mathrm{rpm}$

\begin{tabular}{|c|c|c|c|c|c|}
\hline Pseudo-first-order model & 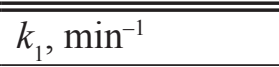 & $q_{e 1}, \mathrm{mg} \mathrm{g}^{-1}$ & $\overline{q_{\text {exp }}, \mathrm{mg} \mathrm{g}^{-1}}$ & & 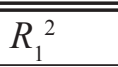 \\
\hline$w 3 \mathrm{~g}$ & 0.0253 & 1.8126 & 4.73 & & 0.6853 \\
\hline$w 5 \mathrm{~g}$ & 0.0281 & 0.4385 & 3.60 & & 0.8314 \\
\hline Pseudo-second order model & $k_{2}, \mathrm{~g} \mathrm{mg}^{-1} \mathrm{~min}^{-1}$ & $q_{e 2}, \mathrm{mg} \mathrm{g}^{-1}$ & $q_{\text {exp }}, \mathrm{mg} \mathrm{g}^{-1}$ & $h, \mathrm{mg} \mathrm{g}^{-1} \min ^{-1}$ & $R_{2}^{2}$ \\
\hline$w 3 \mathrm{~g}$ & 0.2337 & 4.6468 & 4.73 & 4.2796 & 0.9990 \\
\hline$w 5 \mathrm{~g}$ & 0.2956 & 3.5474 & 3.60 & 3.7198 & 0.9992 \\
\hline Intraparticle diffusion model & $k_{i}, \mathrm{mg} \mathrm{g}^{-1} \min ^{-0.5}$ & $I$ & & & $R_{i}^{2}$ \\
\hline$w 3 \mathrm{~g}$ & 0.2625 & 3.4696 & & & 0.9748 \\
\hline$w 5 \mathrm{~g}$ & 0.0791 & 3.0141 & & & 0.8482 \\
\hline
\end{tabular}

Neither kinetic model, however, identified the diffusion mechanism. Thus, the kinetic data were also analyzed by the intraparticle diffusion model. The plot of $q_{t}$ versus $t^{0.5}$ was linear to a certain extent but not linear over the entire time range. It consisted of only two linear sections, presuming the presence of macro and transitional pores in the sorbent structure. As the values of $R_{i}^{2}$ were higher than those of $R_{1}^{2}$ and lower than $R_{2}^{2}$ (Table 6), an explicit conclusion as to whether chemisorption or intraparticle diffusion was the general rate controlling mechanism during CR sorption on BMMC could not be drawn, i.e. either of the proposed processes could dominate during different sorption stages. Adsorbent loading increased when its mass was decreased, as unit sorbent mass came into contact with a larger number of organic molecules. Moreover, the rate of intraparticle diffusion decreased at higher sorbent mass, as indicated 
by the lower values of the rate coefficients $\left(k_{i}\right)$ characterizing the experimental series with $w 3$ $\mathrm{g}$ of biomaterial, when compared to that with $w 5 \mathrm{~g}$ of the sorbent (Table 6). It is likely that the latter was due to the greater external surface area available for adsorption, followed by a sharp drop in the azo dye concentration in the liquid phase and, respectively, a reduction in the process driving force.

\section{CONCLUSION}

The present study provided the following general findings. The observed FTIR adsorbent spectral differences before and after adsorption indicated the possible involvement of carboxyl $(-\mathrm{COOH})$, hydroxyl alcocholic $(-\mathrm{OH})$ and amino $\left(-\mathrm{NH}_{2}\right)$ functional groups on the BMMC surface during the biosorption process and a probable interaction with the sulfonic acid $\left(-\mathrm{SO}_{3} \mathrm{H}\right)$ groups of $\mathrm{CR}$ molecules. The pristine and dye-loaded BMMC were characterized with an irregular and porous surface morphology. The maximum biosorption capacity of Zea mays biomass $\left(q 4.83 \mathrm{mg} \mathrm{g}^{-1}\right)$ was registered at $\mathrm{pH}$ 7. The major mechanisms responsible for CR biosorption include electrostatic interactions between negatively charged dye $\mathrm{SO}_{3}^{-}$groups and positively charged adsorbent surfaces, H-bonding between oxygen- and nitrogen-containing functional groups of $\mathrm{CR}$ and the BMMC surface and hydrophobic-hydrophobic interactions between hydrophobic parts of the dye and the sorbent. The applicability of the Langmuir and/or Freundlich models to the equilibrium experimental data outlined the possibility of monolayer adsorption and/or a heterogeneous energy distribution of active sites on the sorbent surface. The kinetic data followed the pseudo-second order model, but the role and significance of intraparticle diffusion could not be totally neglected. Additionally, the conducted experimental investigations revealed to a certain extent the transport mechanism and mass transfer pathway of the priority pollutant
Congo red in the environmental cycle: industrial wastewaters - natural surface/groundwaters - soil - agricultural crops. More detailed investigations in this direction, however, are still necessary.

Acknowledgements. This study was supported financially by Project No. 07/2011, Faculty of Veterinary Medicine, Trakia University, Stara Zagora, Bulgaria.

\section{NOMENCLATURE}

$a_{\mathrm{L}} \quad$ Langmuir isotherm constant, $\mathrm{dm}^{3} \mathrm{mg}^{-1}$

$a_{\mathrm{R}} \quad$ Redlich-Peterson isotherm constant, $\mathrm{dm}^{3} \mathrm{mg}^{-1}$

$b \quad$ Redlich-Peterson isotherm constant $(0<\mathrm{b}<1)$

$C_{e} \quad$ equilibrium sorbate concentration in the liquid phase, $\mathrm{mg} \mathrm{dm}^{-3}$

$C_{o}$ initial sorbate concentration in the liquid phase, $\mathrm{mg} \mathrm{dm} \mathrm{m}^{-3}$

$d_{p} \quad$ particle diameter, $\mathrm{mm}$

$h \quad$ initial sorption rate, $\mathrm{mg} \mathrm{g}^{-1} \mathrm{~min}^{-1}$

$K_{\mathrm{L}} \quad$ Langmuir isotherm constant, $\mathrm{dm}^{3} \mathrm{~g}^{-1}$

$K_{\mathrm{F}} \quad$ Freundlich isotherm constant, $\mathrm{dm}^{3} \mathrm{~g}^{-1}$,

$k_{i} \quad$ intraparticle diffusion rate constant, $\mathrm{mg} \mathrm{g}^{-1} \min ^{-0.5}$

$K_{\mathrm{R}} \quad$ Redlich-Peterson isotherm constant, $\mathrm{dm}^{3} \mathrm{~g}^{-1}$

$k_{1} \quad$ rate constant of pseudo-first order sorption, $\mathrm{min}^{-1}$

$k_{2} \quad$ rate constant of pseudo-second order sorption, $\mathrm{g}$ $\mathrm{mg}^{-1} \min ^{-1}$

$m$ biosorbent concentration, $\mathrm{g} \mathrm{dm}^{-3}$

$n \quad$ agitation rate, $\mathrm{rpm}$

$n_{\mathrm{F}} \quad$ heterogeneity factor in the Freundlich model

$q_{e} \quad$ equilibrium sorbate concentration in the solid phase, $\mathrm{mg} \mathrm{g}^{-1}$

$q_{t} \quad$ sorption capacity at time $t, \mathrm{mg} \mathrm{g}^{-1}$

$R^{2} \quad$ correlation coefficient

$T$ temperature, $\mathrm{K}$

$t$ time, $\min$

$V \quad$ solution volume, $\mathrm{dm}^{3}$

$w \quad$ biosorbent mass, $\mathrm{g}$

$\lambda$ maximum absorbance wavelength, $\mathrm{nm}$

$\chi^{2} \quad$ Chi-square error 


\section{REFERENCES}

[1] D. T. Sponza, M. Isik, Toxicity and intermediates of C.I. Direct Red 28 dye through sequential anaerobic/aerobic treatment, Process Biochem., 40, 2735-2744 (2005).

[2] X. Han, W. Wang, X. Ma, Adsorption characteristics of methylene blue onto low cost biomass material lotus leaf, Chem. Eng. J., 171, 1-8 (2011).

[3] A. Tor, Y. Cengeloglu, Removal of congo red from aqueous solution by adsorption onto acid activated red mud, J. Hazard. Mater., B138, 409-415 (2006).

[4] Azo Dyestuffs and ECOTEX testing for Europe STR, www.erols.com/strlab/azodyes.htm.

[5] L. Wang, A. Wang, Adsorption properties of Congo red from aqueous solution onto N,O-carboxymethyl-chitosan, Bioresour. Technol., 99, 14031408 (2008).

[6] R. Sabnis, Handbook of Biological Dyes and Stains. Synthesis and Industrial Applications, Springer, John Wiley \& Sons, New Jersey, USA, 106-107, 2010.

[7] H. M. Pinheiro, E. Touraud, O. Thomas, Aromatic amines from azo dye reduction: Status review with emphasis on direct UV spectrophotometric detection in textile industry wastewaters, Dyes Pigm., 61, 121-139 (2004).

[8] C. Smaranda, M. Gavrilescu, D. Bulgariu, Studies on sorption of Congo Red from aqueous solution onto soil, Int. J. Environ. Res., 5, 1, 177-188, (2011).

[9] V. Vimonses, S. Lei, B. Jin, C.W.K. Chow, C. Saint, Kinetic study and equilibrium isotherm analysis of Congo Red adsorption by clay materials, Chem. Eng. J., 148, 354-364 (2009).

[10] T. Sen, S. Afroze, H. M. Ang, Equilibrium, kinetics and mechanism of removal of methylene blue from aqueous solution by adsorption onto pine cone biomass of Pinus radiate, Water Air Soil Poll., 218, 499-515 (2011).

[11] N. Rajamohan, Equilibrium studies on sorption of an anionic dye onto acid activated water hyacinth roots, African J. Environ. Sci. Technol., 3, 11, 399404 (2009).

[12] R. Han, L. Zhang, C. Song, M. Zhang, H. Zhu, L. Zhang, Characterization of modified wheat straw, kinetic and equilibrium study about copper ion and methylene blue adsorption in batch mode, Carbohydr. Polym., 79, 1140-1149 (2010).
[13] U. Farooq, M. A. Khan, W. Athar, J. A. Kozinski, Effect of modification of environmentally friendly biosorbent wheat (Triticum aestivum) on the biosorptive removal of cadmium(II) ions from aqueous solution, Chem. Eng. J., 171, 400-410 (2011).

[14] S. Vieira, Z. M. Magriotis, N. A. V. Santos, M. G. Cardoso, A. A. Saczk, Macauba palm (Acrocomia aculeata) cake from biodiesel processing: An efficient and low cost substrate for the adsorption of dyes, Chem. Eng. J., 183, 152-161 (2012).

[15] Z. Zhang, L. Moghaddam, I. M. O'Hara, W. O. S. Doherty, Congo Red adsorption by ball-milled sugarcane bagasse, Chem. Eng. J., 178, 122-128 (2011).

[16] Z. Yaneva, N. Georgieva, Insights into Congo Red adsorption on agro-industrial materials - spectral, equilibrium, kinetic, thermodynamic, dynamic and desorption studies. A review, IRECHE, 4, 2, 127-146 (2012).

[17] M. Elizalde-Gonzalez, J. Mattusch, R. Wennrich, Chemically modified maize cobs waste with enhanced adsorption properties upon methyl orange and arsenic, Bioresour. Technol., 99, 5134-5139 (2008).

[18] M. F. Elahmadia, N. Bensalahb, A. Gadria, Treatment of aqueous wastes contaminated with Congo Red dye by electrochemical oxidation and ozonation processes, J. Hazard. Mater., 168, 1163-1169 (2009).

[19] H. P. Boehm, Some aspects of the surface chemistry of carbon blacks and other carbons, Carbon, 32, 759-769 (1994).

[20] G. Issabayeva, M. K. Aroua, N. Meriam, N. Sulaiman, Removal of lead from aqueous solutions on palm shell activated carbon, Bioresour. Technol., 97, 2350-2355 (2006).

[21] B. H. Hameed, Evaluation of papaya seed as a novel non-conventional low-cost adsorbent for removal of methylene blue, J. Hazard. Mater., 162, 939-994 (2010).

[22] Koumanova, P. Peeva-Antova, Adsorption of $p$ chlorophenol from aqueous solutions on bentonite and perlite, J. Hazard. Mater., 90, 3, 229-234 (2002).

[23] I. Langmuir, The constitution and fundamental properties of solids and liquids, J. Am. Chem. Soc., 38, 2221 (1916).

[24] H. Freundlich, Über die Adsorption in Lösungen, J. Phys. Chem., 57, 385-470 (1907).

[25] O. Redlich, D. L. Peterson, A useful adsorption isotherm, J. Phys. Chem., 63, 1024-1026 (1959). 
[26] S. Lagergren, Zur theorie der sogenannten adsorption gelöster stoffe, Kungliga Svenska Vetenskapsakademiens. Handlingar, 24, 1-39 (1898).

[27] Y. S. Ho, G. McKay, Kinetic model for lead(II) sorption onto peat, Adsorpt. Sci. Technol., 16, 243-255 (1998).

[28] S. Z. Roginsky, Y. Zeldovich, Acta Phys. Chem. USSR, 1, 554 (1934).

[29] S. H. Chien, W. R. Clayton, W. R. Application of Elovich equation to the kinetics of phosphate release and sorption on solids. Soil Sci Am J, 4, 265-268 (1980).

[30] V. Vimonses, B Jin, C. W. K. Chow, Insight into removal kinetic and mechanisms of anionic dye by calcined clay materials and lime, J. Hazard. Mater., 177, 420-427 (2010).

[31] Y. Yang, G. Wang, B. Wang, Z. Li, X. Jia, Q. Zhou, Y. Zhao, Biosorption of Acid Black 172 and Congo Red from aqueous solution by nonviable Penicillium YW 01: Kinetic study, equilibrium isotherm and artificial neural network modeling, Bioresour. Technol., 102, 828-834 (2011).
[32] R. Ahmad, R. Kumar, Adsorptive removal of Congo red dye from aqueous solution using bael shell carbon, Appl. Surf. Sci., 257, 1628-1633 (2010).

[33] P. Kumar, S. Ramalingam, C. Senthamarai, M. Niranjanaa, P. Vijayalakshmi, S. Sivanesan, Adsorption of dye from aqueous solution by cashew nut shell: Studies on equilibrium, isotherm, kinetics and thermodynamics of interactions, Desalination, 261, 52-60 (2010).

[34] L. Nadjia, E. Abdelkader, B. Ahmed, Photodegradation study of Congo Red in aqueous solution using $\mathrm{ZnO} / \mathrm{UV}-\mathrm{A}$ : Effect of $\mathrm{pH}$ and band gap of other semiconductor groups, J. Chem. Eng. Process. Technol., 2, 2, 1-9 (2011).

[35] M. Movahedi, A.R. Mahjoub, S. Janitabar-Darzi, Photodegradation of Congo Red in aqueous solution on $\mathrm{ZnO}$ as an alternative catalyst to $\mathrm{TiO}_{2}, J$. Iran. Chem. Soc., 6, 3, 570-577 (2009).

[36] Z. Hu, H. Chen, F. Ji, S. Yuan, Removal of Congo Red from aqueous solution by cattail root, J. Hazard. Mater., 173, 292-297 (2010). 
